\title{
Mast cell degranulation in rat uterine cervix during pregnancy correlates with expression of vascular endothelial growth factor mRNA and angiogenesis
}

\author{
V L Bosquiazzo, J G Ramos, J Varayoud, M Muñoz-de-Toro and E H Luque \\ Laboratorio de Endocrinología y Tumores Hormonodependientes, School of Biochemistry and Biological Sciences, \\ Universidad Nacional del Litoral, Casilla de Correo 242, 3000 Santa Fe, Argentina
}

Correspondence should be addressed to E H Luque; Email: eluque@fbcb.unl.edu.ar

\begin{abstract}
Vascular growth of the uterine cervix during pregnancy is associated with mast cell (MC) degranulation. To better understand the mechanism underlying this process, uterine cervices of intact pregnant rats were dissected and endothelial cell proliferation was measured by a bromodeoxyuridine incorporation technique. Total vascular endothelial growth factor (VEGF) mRNA expression and the relative abundance of VEGF splice variants $(120,164$, and 188) were determined by RT-PCR. VEGF protein expression was evaluated by immunohistochemistry. To investigate the role of MCs on cervical angiogenesis, a second set of pregnant animals were treated with an MC stabilizer (disodium cromoglycate) to inhibit $M C$ degranulation. Furthermore, 17 $\beta$-estradiol $\left(E_{2}\right)$ serum levels were established by RIA. In intact pregnant rats, VEGF mRNA expression was positively correlated with endothelial cell proliferation and circulating $E_{2}$ levels. All selected splice variants of VEGF gene were detected and their relative abundance did not show any change throughout pregnancy. Animals treated with disodium cromoglycate showed a decrease in endothelial cell proliferation and in VEGF mRNA expression compared with controls. Relative abundance of VEGF mRNA splice variants and $E_{2}$ serum levels showed no differences between these experimental groups. These results show a time-dependent correlation between VEGF mRNA expression and $E_{2}$ serum levels in the uterine cervix of intact pregnant rats, while MC stabilizer-treated animals reduced the VEGF expression without modifying $E_{2}$ serum levels. We suggest that cervical angiogenesis during pregnancy could be regulated by a mechanism which involves endogenous $E_{2}$ and chemical mediators stored in MC granules via a VEGFdependent pathway.

Reproduction (2007) 133 1045-1055
\end{abstract}

\section{Introduction}

Vascular supply is a fundamental requirement for reproductive functions (Ferrara \& Davis-Smyth 1997, Goth et al. 2003). Angiogenesis occurs regularly in association with cyclical changes in adult female endometrium and also during implantation and subsequent placentation (Heryanto \& Rogers 2002). During pregnancy and parturition, the uterine cervix undergoes adaptation processes, such as polymorphonuclear leukocyte infiltration and collagen remodeling (Luque et al. 1996, 1998). All these processes demand energy and a vascular system providing sufficient nutrient supply is essential. Using intact pregnant rats, we have demonstrated that the vascular tree of the uterine cervix is an active cellular compartment showing striking changes in the relative area occupied by vessels and in endothelial proliferation (Varayoud et al. 2004). These cellular events reflect an active angiogenic process throughout gestation.

Considerable attention has been focused on the regulation of angiogenesis and vascular permeability in the female reproductive tract (Goede et al. 1998, Rabbani \& Rogers 2001). One of the best-studied proangiogenic mediators is the vascular endothelial growth factor (VEGF) that often represents a critical rate-limiting step in physiological processes (Hyder et al. 1996). VEGF-A (often referred to as simply VEGF), VEGF-B, VEGF-C, VEGF-D, VEGF-E, and placental growth factor constitute the platelet-derived growth factor subfamily of the cysteine knot proteins. They show high structural homology but they represent distinct gene products (Halder et al. 2000, Byrne et al. 2005, Roy et al. 2006). VEGF-A mRNA and protein exist as multiple isoforms resulting from alternative splicing of the eight coding exons named according to the amino 
acid number of the monomer. VEGF188 includes all eight exons, whereas deletion of exon 6 or exons 6 and 7 generates VEGF164 and VEGF120 isoforms respectively (Cullinan-Bove \& Koos 1993, Hyder et al. 1996, Mowa et al. 2004). Other alternative spliced forms have also been reported in rodents, such as VEGF144 and VEGF115 (Sugihara et al. 1998, Ding et al. 2006). VEGF isoforms differ primarily in their bioavailability, which is conferred by heparin and heparan sulfatebinding domains encoded by exons 6 and 7 . VEGF120 might diffuse relatively free in tissue, whereas approximately half of the VEGF164 binds to cell surface heparan sulfate proteoglycans (HSPGs). VEGF188 remains almost completely sequestered by HSPGs in the cell surface and in the extracellular matrix, making HSPGs a reservoir of VEGF that can be mobilized through proteolysis (Ferrara et al. 2003, Puxeddu et al. 2005). These differences in the biochemical properties of the splice variants could promote different physiological roles and bring a complex network that regulates the angiogenesis in the female reproductive tract.

A close relationship between endocrine function and angiogenesis has been observed during estrous cycle (Karuri et al. 1998) and early pregnancy (Walter et al. 2005). The steady-state level of VEGF mRNA increases rapidly in the uterus following estrogen $(\mathrm{Eg})$ treatment (Cullinan-Bove \& Koos 1993, Hyder et al. 2000). This effect suggests that Eg regulates vascular permeability of uterine blood vessels through modulation of VEGF expression. In agreement, Karuri et al. (1998) showed that a twofold increase in VEGF mRNA content in the rat uterine tissue at proestrous is exhibited, coincident with the highest $17 \beta$-estradiol $\left(\mathrm{E}_{2}\right)$ levels. Moreover, a localized increase in uterine vascular permeability and angiogenesis are the hallmarks of initiation and progression of blastocyst implantation and it is likely that VEGF signaling influences these events (Halder et al. 2000). The angiogenesis of the rodent uterus is also regulated by progesterone (Pg) by stimulating endothelial cell proliferation and VEGF expression (Cullinan-Bove \& Koos 1993, Ma et al. 2001, Walter et al. 2005). Based on these results, VEGF expression is likely to be under the control of both steroid hormones; however, there is a need for a better understanding of the endocrine regulation of angiogenesis in the reproductive tract under physiological conditions.

Besides endocrine control, the immune system also plays an important role in the regulation of angiogenesis. Several studies indicate that leukocytes can induce vascular growth and specific leukocyte-derived cytokines have been identified as proangiogenic factors (Camussi et al. 1997, Griffioen \& Molema 2000, Ribatti et al. 2001). We previously demonstrated that mast cell (MC) degranulation correlates with new blood vessel formation in the rat uterine cervix during the second half of gestation (Varayoud et al. 2004). This physiological control could be orchestrated with other immune cells, like macrophages, since $\mathrm{MC}$ degranulation influences macrophage content of the uterine cervix (Bosquiazzo et al. 2005). Therefore, based on our previous work and taking into account that MCs actively participate in the angiogenesis of tumors through the production of VEGF (Aoki et al. 2003), we suggest that VEGF could be a mediator of MC-induced angiogenesis in the rat uterine cervix.

To better understand the regulation of angiogenesis in the uterine cervix during pregnancy, we evaluated the correlation between endothelial cell proliferation and VEGF gene expression. Since MCs promote cervical angiogenesis by a degranulation-mediated process (Varayoud et al. 2004), we tested here whether VEGF mRNA content is also influenced by MC degranulation.

\section{Materials and Methods}

\section{Animals}

Female adult rats (200-250 g body weight (BW)) of a Wistar-derived strain bred at the Department of Human Physiology (Santa Fe, Argentina) were used. Animals were maintained under controlled environment $(22 \pm$ $2{ }^{\circ} \mathrm{C}$; lights on from 0600 to $2000 \mathrm{~h}$ ) and had free access to pelleted rodent chow (Cooperación, Buenos Aires, Argentina) and tap water. To obtain pregnant specimens, proestrous females were caged overnight with males with proven fertility. Pregnancy was confirmed by the presence of spermatozoa in the vaginal smear the morning after coitus, defined as day 1 of pregnancy (D1; Freeman 1988, Montes \& Luque 1988). In this colony, delivery occurred on D23. To determine serum $\mathrm{E}_{2}$ levels, peripheral blood was collected from jugular vein on D3-D5, D12, D14, D15, D18, D22, and D23 (three to four animals per day) of gestation. Serum samples were stored at $-20{ }^{\circ} \mathrm{C}$ until used for hormone assays. All rats were handled in accordance with the principles and procedures outlined in the Guide for the Care and Use of Laboratory Animals issued by the US National Academy of Sciences.

\section{Treatment and experimental design}

Pregnant rats were randomly assigned to each experimental group (at least six animals per group). To evaluate endothelial cell proliferation and VEGF mRNA expression during pregnancy, whole cervices were dissected on D12, D14, D18, and D22 of gestation. Another set of pregnant rats was used to evaluate the effects of MC stabilizer treatment on VEGF mRNA expression. These rats were treated either with the MC stabilizer, disodium cromoglycate (i.p. $87 \mathrm{mg} / \mathrm{kg}$ BW, Sigma Chemical $\mathrm{Co}$ ) or with saline solution (control) daily from D12 to D18 and killed $3 \mathrm{~h}$ after the last injection. Day 12 of gestation was selected as onset of administration of cromoglycate because it is coincident with a high level of $M C$ infiltration in the rat uterine 
cervix (Varayoud et al. 2004) and to avoid putative interferences with implantation and/or early developmental stages. The absence of acute or chronic toxicity signs in treated mothers and the effectiveness of this experimental protocol on the inhibition of MC degranulation were previously evaluated in our laboratory (Varayoud et al. 2004).

All animals were injected intraperitoneally with the thymidine analog bromodeoxyuridine (BrdU, $60 \mathrm{mg} / \mathrm{kg}$ BW, Sigma) $2 \mathrm{~h}$ before killing. Animals were killed by decapitation, blood was collected, and serum stored at $-20{ }^{\circ} \mathrm{C}$ until used for hormone assays. Whole uterine cervix was either fixed by immersion in $10 \%(\mathrm{v} / \mathrm{v})$ buffered formalin for $6 \mathrm{~h}$ at $4{ }^{\circ} \mathrm{C}$ or flash frozen in liquid nitrogen. Fixed tissue was embedded in paraffin for immunohistochemistry. Frozen tissue was stored at $-80{ }^{\circ} \mathrm{C}$ until RNA extraction.

\section{$R T$ and competitive PCR}

\section{Synthesis of competitor DNA fragments}

PCR was performed using a template purified $\lambda$ phage DNA ( $\lambda$ DNA) and specific oligonucleotide primers for the rat VEGF mRNA (Table 1 and Fig. 1). Forty cycles of amplification were carried out at low annealing temperatures by allowing the oligonucleotide primers to bind randomly to $\lambda D N A$ generating DNA fragments with different molecular weights. The reaction tube contained Pyrococcus furiosus DNA polymerase (Promega Corporation), $2 \mathrm{mM} \mathrm{MgCl} 2,0.2 \mathrm{mM}$ of each of the four deoxyNTPs (Invitrogen), and 20 pmol of each primer (Invitrogen) in a final volume of $25 \mu \mathrm{l}$ of $1 \times$ PCR buffer (Triton X-100, Tris-ClH, $\mathrm{KCl},\left(\mathrm{NH}_{4}\right)_{2} \mathrm{SO}_{4}, \mathrm{BSA}$, and $\left.\mathrm{Cl}_{2} \mathrm{Mg}\right)$. After initial denaturation at $97^{\circ} \mathrm{C}$ for $5 \mathrm{~min}$, the reaction mixture was subjected to successive cycles of denaturation at $96^{\circ} \mathrm{C}$ for $45 \mathrm{~s}$, annealing at $42^{\circ} \mathrm{C}$ for $1 \mathrm{~min}$, and extension at $72{ }^{\circ} \mathrm{C}$ for $1 \mathrm{~min}$. A final extension cycle at $72{ }^{\circ} \mathrm{C}$ for 5 min was included. The generated fragments were resolved on 3\% $(\mathrm{w} / \mathrm{v})$ agarose gels containing ethidium bromide (Sigma) and molecular weights were determined by comparing with DNA standards (Cien Marker, Biodynamics, Buenos Aires, Argentina). A DNA fragment with a very similar molecular weight to the cDNA target was selected and purified using the Wizard-SV Gel and PCR Clean-Up System (Promega). This fragment was inserted and cloned into a plasmid vector (pBluescript SK, Stratagene, La Jolla, CA, USA) and used as a competitor in subsequent PCRs for VEGF mRNA quantitation. The competitor DNA concentration was assessed with a spectrophotometer (Beckman Instruments Inc., Fullerton, CA, USA) at 260 ๆm.

\section{Reverse transcription (RT)}

Following manufacturer's instructions, RNA extractions were performed using TRIzol reagent (Invitrogen). The quantity of total RNA was assessed with a spectrophotometer at a wavelength of $260 \eta \mathrm{m}$. Equal quantities $(4 \mu \mathrm{g})$ of total RNA were RT into cDNA with $300 \mathrm{U}$ Moloney murine leukemia virus reverse transcriptase (MMLV-RT, Promega) using $0.5 \mu \mathrm{g}$ random primers (Invitrogen). Twenty units of RNase inhibitor (RNAout, Invitrogen) and $10 \eta \mathrm{mol}$ deoxy-NTP mixture were added to each reaction tube in a final volume of $30 \mu \mathrm{l}$ of $1 \times$ MMLV-RT buffer (Promega). RT was performed at $37^{\circ} \mathrm{C}$ for $60 \mathrm{~min}$. Reactions were terminated by heating at $80^{\circ} \mathrm{C}$ for $5 \mathrm{~min}$ and cooling at $4{ }^{\circ} \mathrm{C}$, followed by dilution of the reverse-transcribed cDNA with RNasefree water to a final volume of $60 \mu \mathrm{l}$. RNA incubated under identical conditions, but without reverse transcriptase, served as a negative control.

\section{Competitive PCR to evaluate VEGF mRNA expression}

An optimized competitive PCR protocol was employed to analyze the expression levels of VEGF mRNA transcripts. Total uterine cervix cDNA was pooled from pregnant females (two animals per pool and three pools per gestational day) and competitive PCR was performed with each pool of cDNA. Constant amounts of target cDNA were added to all reaction tubes together with crescent quantities of competitor DNA (0.88-10.7 attomoles). Each reaction mixture contained $2.5 \mathrm{U}$ Taq DNA polymerase, $1 \mathrm{mM} \mathrm{MgCl} 2,0.2 \mathrm{mM}$ of each of the four deoxy-NTPs, and 20 pmol of each VEGF specific primer (all from Invitrogen; Table 1) in a final volume of $25 \mu \mathrm{l}$ of $1 \times$ PCR Taq buffer (Invitrogen). After initial denaturation at $97^{\circ} \mathrm{C}$ for $5 \mathrm{~min}$, the reaction mixture was subjected to successive cycles of denaturation at $96{ }^{\circ} \mathrm{C}$ for $45 \mathrm{~s}$, annealing at $60{ }^{\circ} \mathrm{C}$ for $1 \mathrm{~min}$, and extension at $72{ }^{\circ} \mathrm{C}$ for $1 \mathrm{~min}$. A final extension cycle at $72{ }^{\circ} \mathrm{C}$ for $5 \mathrm{~min}$ was included. The optimal number of cycles, determined in the

Table 1 Sequence of PCR primers.

\begin{tabular}{lll}
\hline Primer & Sequence & Product size \\
\hline & & 320 bp \\
VEGF sense & 5'CTGCTCTCTTGGGTGCACTGG-3' $^{\prime}$ & VEGF120: 126 bp \\
VEGF antisense & $5^{\prime}$-GGTTTGATCCGCATGATCTGCAT-3' $^{\prime}$ & VEGF164: 258 bp \\
VEGF isoform sense & $5^{\prime}$-CATGCGGATCAAACCTCACC-3' & VEGF188: 330 bp \\
VEGF isoform antisense & $5^{\prime}$-CACCGCCTTGGCTTGTCACA-3' & 290 bp \\
L19 sense & & \\
L19 antisense & $5^{\prime}$-GAAATCGCCAATGCCAACTC-3' & \\
\hline
\end{tabular}




\begin{tabular}{|c|c|c|c|c|}
\hline $344 b p$ & $72 b p$ & $132 \mathrm{bp}$ & $18 \mathrm{bp}$ & \\
\hline Exon 1 - 5 & & & 8 & VEGF120 \\
\hline Exon $1-5$ & & 7 & 8 & VEGF164 \\
\hline Exon 1 - 5 & 6 & 7 & 8 & VEGF188 \\
\hline
\end{tabular}

Figure 1 Illustration of the vascular endothelial growth factor (VEGF) gene amplification by RT-PCR. Primers 1 and 2 were used to quantify the VEGF mRNA by competitive PCR, whereas primers 3 and 4 were applied to detect the major splice variants. The expected sizes of CDNA fragments after PCR amplification are shown in Table 1.

exponential phase of the reaction was 30 . The sequence of primers for VEGF mRNA was selected based on the published cDNA sequences of the rat VEGF mRNA (Kashida et al. 2001). In all assays, negative controls without cDNA target were performed to minimize the introduction of potential artifacts. Using the TA cloning kit (Invitrogen), PCR products corresponding to VEGF were cloned, and specificity was confirmed by DNA sequencing (data not shown). The generated fragments (cDNA target and competitor DNA) were resolved on $3 \%(\mathrm{w} / \mathrm{v})$ agarose gels containing ethidium bromide (Sigma) and their molecular weight determined by comparing with DNA standards (Biodynamics). Agarose gel images were digitized using a Sony ExwaveHAM color video camera (Sony Electronics Inc., Park Ridge, NJ, USA) and the Image Pro-Plus 4.1.0.1 image system analyzer (Media Cybernetics, Silver Spring, MD, USA). The integrated optical density (IOD) for each PCR product was obtained by densitometry. The logarithm of the ratio of competitor and VEGF-IOD was plotted as a function of the logarithm of the concentration of competitor added to each PCR tube. The concentration of VEGF mRNA for each day of gestation in the uterine cervix was determined when the ratio of competitor/ VEGF-IOD was equal to 1.

To confirm that changes in VEGF mRNA were specific, steady-state levels of a constitutively expressed cellular mRNA (L19 ribosomal protein) were measured using specific primers (Table 1; Chan et al. 1987).

\section{Analysis of VEGF mRNA splice variants by RT-PCR}

To detect the main VEGF mRNA splice variants (120, 164, and 188), RT reactions were carried out as mentioned previously. Total uterine cervix cDNA was pooled from six rats (two animals per pool) on each gestational day and PCRs were performed as described previously, using an annealing temperature of $61^{\circ} \mathrm{C}$. To co-amplify the VEGF mRNA variants, the sense and antisense primers were located flanking the alternative splicing sites corresponding to exons 6 and 7 of the VEGF cDNA sequence (GenBank accession no.: NM_031836, Table 1 and Fig. 1). Melting curves showed the absence of heteroduplex formation and unspecific amplification products (Eckhart et al. 1999). The PCR products were resolved on $2 \%(\mathrm{w} / \mathrm{v})$ agarose gels, cloned, and sequenced (data not shown). The relative expression of each splice variant was evaluated determining the IOD by densitometry.

\section{Hormone assays}

Serum levels of $E_{2}$ were determined by RIA using $\left[2,4,6,7,16,17-{ }^{3} \mathrm{H}\right] \mathrm{E}_{2}$ (Perkin-Elmer Life and Analytical Sciences Inc., Boston, MA, USA) and a specific antibody provided by $\mathrm{Dr}$ GD Niswender. $\mathrm{E}_{2}$ concentration was measured after ethyl ether extraction (Merck; Kass et al. 2004). The sensitivity of the assay was $1.6 \mathrm{pg} / \mathrm{ml}$, and the intra- and interassay coefficients of variation were 10.16 and $7.90 \%$ respectively.

\section{Immunohistochemistry and morphometry}

BrdU incorporation was used to evaluate proliferating endothelial cells (Kass et al. 2000) rat mast cell proteinase-I (RMCP-I) to identify MCs (Gibson \& Miller 1986) and anti-VEGF to determine the cellular sites and expression patterns of VEGF. Immunostaining for MCs was performed following the immunoperoxidase technique after periodic acid and sodium borohydrate incubation to block endogenous peroxidase activity. Detection of BrdU incorporation was performed as previously described, including the acidic hydrolysis for DNA denaturation and microwave (MW) pretreatment for antigen retrieval (Kass et al. 2000). VEGF immunodetection was done following the previously described protocol (Bosquiazzo et al. 2005). Primary antibodies were incubated overnight at $4{ }^{\circ} \mathrm{C}$, and dilutions used were anti-BrdU 1:100 (clone 85-2C8, Novocastra Laboratories Ltd, Newcastle-upon-Tyne, UK), anti-RMCP-I 1:200 (Moredun Scientific Ltd, Edinburgh, Scotland), and anti-VEGF 1:40 (clone C-1, Santa Cruz Biotechnology, Santa Cruz, CA, USA). Reaction was developed using the avidin-biotin peroxidase method and diaminobenzidine (Sigma) was used as a chromogen substrate. Samples were counterstained with Harris hematoxylin (Biopur, Rosario, Argentina) for BrdU and Mayer's hematoxylin for RMCP-I and VEGF. The slides were dehydrated and mounted with permanent mounting medium (PMyR Buenos Aires, Argentina). Each immunohistochemical run included positive and negative controls. For negative controls, the primary antibody was replaced with nonimmune rabbit serum (Sigma) or the immunohistochemical run was performed in samples from animals that did not receive BrdU. Suppliers had tested the specificity of the primary antibodies used.

The evaluation of tissue sections was done using an Olympus BH2 microscope (Olympus Optical Co. Ltd, 
Tokyo, Japan) with a Dplan $100 \times$ objective (Olympus). The percentage of proliferating endothelial cells was measured on sections immunostained with an anti-BrdU antibody and was calculated by dividing the number of BrdU-positive endothelial cells by the total number of endothelial cells. Two sections of each uterine cervix were analyzed and approximately 200 vessels/section were evaluated.

To evaluate the effect of MC-stabilizing treatment, the percentage of degranulated MCs in immunohistochemical sections was compared between MC stabilizer-treated and control rats on D18 of pregnancy. MC was considered as degranulated, with more than three granules outside of the cell shape or with empty cavities in the cytoplasm (Gunin \& Sharov 1998, Varayoud et al. 2004). VEGF immunostaining expression was established using a semiquantitative method.

\section{Statistical analysis}

The statistical analysis was performed by Kruskal-Wallis one-way ANOVA and significance between groups was determined by Dunn's post hoc test. Correlations were performed using Pearson analysis. To assign probabilities of the difference between two groups, the MannWhitney $U$ test was used (Siegel 1956).

\section{Results}

VEGF mRNA expression, endothelial cell proliferation, and serum levels of $E_{2}$ are positively correlated during pregnancy

The design of the primers and the competitive RT-PCR were suitable to quantify VEGF mRNA expression in the uterine cervix throughout gestation. The slope and $r^{2}$ of the competitor/VEGF rate plotted as a function of increasing amounts of competitor did not differ between the different time points analyzed, indicating high reproducibility and accuracy of the amplification process (Fig. 2). The VEGF mRNA expression levels changed significantly during pregnancy showing higher expression on D14 and D18 of gestation when they were compared with D12 and D22 $(P<0.05$; Fig. $3 \mathrm{~A})$. A similar temporal pattern was exhibited by endothelial cell proliferation during pregnancy, with higher BrdU incorporation rates on D14 and D18 of gestation compared with D12 (Fig. 3B). VEGF mRNA expression was positively correlated with endothelial cell proliferation (Fig. 3C). Figure 3D shows a BrdUpositive endothelial cell in the uterine cervix blood vessels.

$E_{2}$ serum levels of pregnant animals belonging to our colony are shown in Fig. 4A. Positive correlations were found between $E_{2}$ serum levels and VEGF mRNA (Fig. 4B) or BrdU incorporation (Fig. 4C) on D12, D14, D18, and D22.
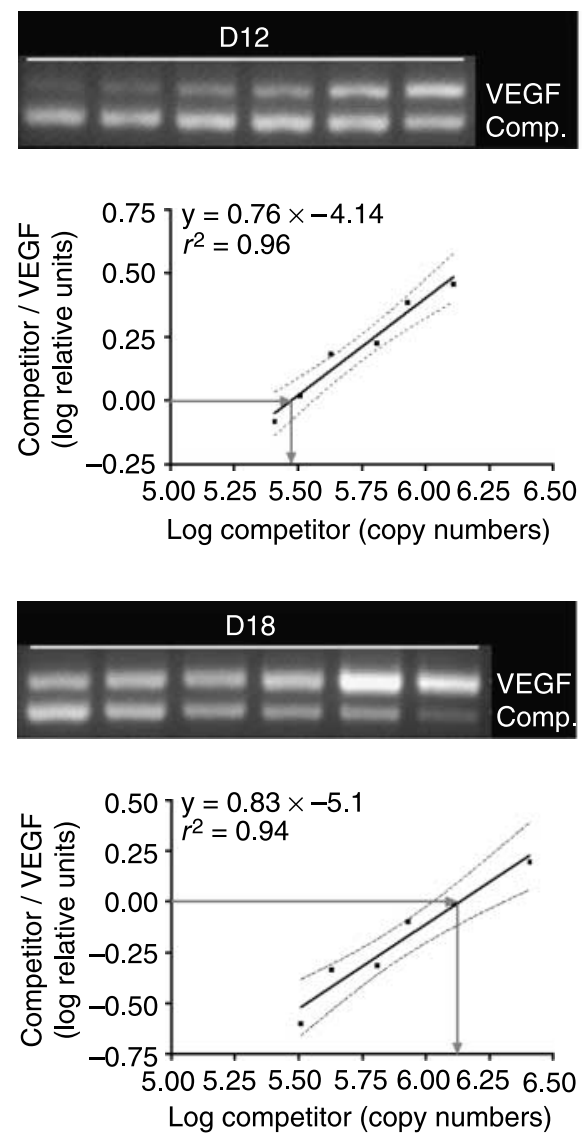

www.reproduction-online.org
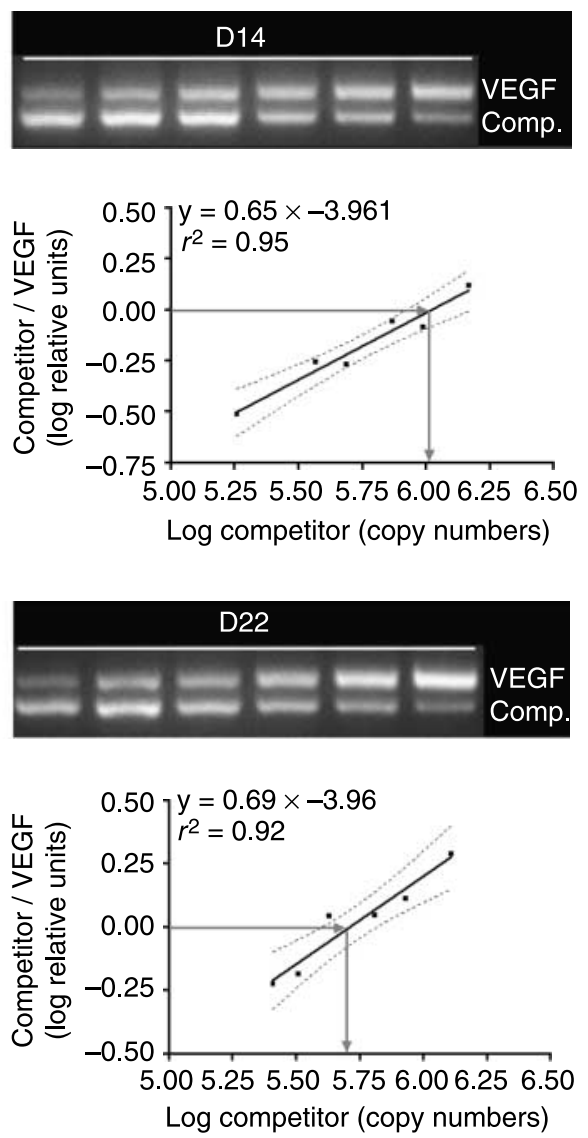

Figure 2 Competitive RT-PCR of VEGF mRNA in the uterine cervix during pregnancy. Representative agarose gels stained with ethidium bromide from each studied day of gestation showed VEGF target and competitor products. VEGF transcripts were obtained from total RNA using primers upstream from the alternative splicing site. Arrows indicate the log of the equivalent points (defined as the IOD ratio of competitor and VEGF equal to 1) and values on the abscissa mark the corresponding VEGF mRNA copy numbers. 

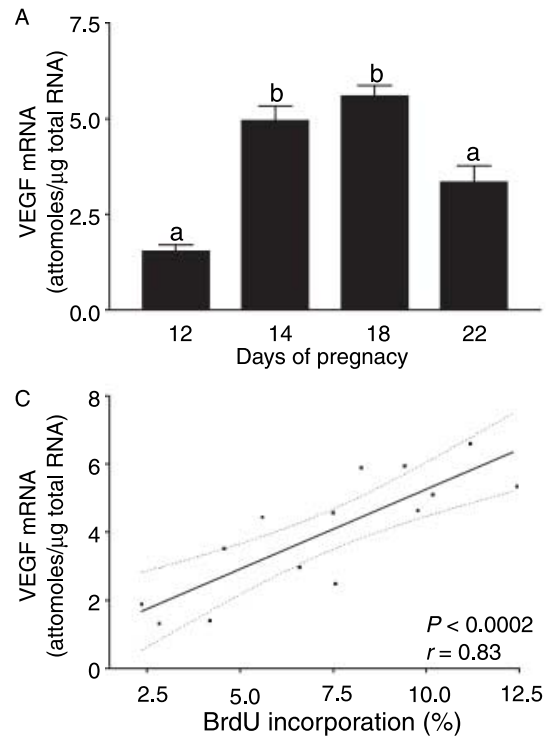

\section{Alternative splice variants of VEGF mRNA do not change during pregnancy}

We examined the expression of alternative splice variants of VEGF mRNA by RT-PCR using oligonucleotide primers that encompass exons 6 and 7 (Fig. 1 and Table 1). Three different splice variants of VEGF mRNA (VEGF120, VEGF164, and VEGF188) were detected by RT-PCR in the rat uterine cervix during the second half of gestation (Fig. 5A). The relative expression levels of these transcripts were as follows: VEGF164>VEGF188> VEGF120, and the relative contribution of each other to the total expression did not show any change clearly suggesting that the splicing mechanism of the VEGF mRNA was not modified throughout gestation (Fig. 5B).

\section{MC degranulation correlates with VEGF expression in the uterine cervix during pregnancy}

To investigate whether MCs could regulate angiogenesis via a VEGF-dependent pathway; pregnant rats were treated with an MC stabilizer from D12 to D18 of gestation. A polyclonal antibody against RMCP-I was successfully used to identify both non-degranulated and degranulated MCs (Fig. 6A). Densely packed granules were found in the cytoplasm of immunostained non-degranulated MCs (Fig. 6B). Evidence of degranulation were defined by the presence of granules released to the pericellular space and of cytoplasmic halos in MCs (Fig. 6C). Pregnant rats treated with MC stabilizer had more than $40 \%$ of non-degranulated MCs, whereas controls showed signs of degranulation in the majority of the MCs (Fig. 6D). These results provide evidence that the MC stabilizer treatment is effective.

To discard possible effects of disodium cromoglycate treatment on the Eg synthesis and metabolism, $E_{2}$ serum levels were measured on D18 of pregnancy showing no changes in $E_{2}$ concentration in $M C$ stabilizer-treated rats compared with controls (Fig. 7A). In contrast, endothelial cell proliferation and VEGF mRNA expression significantly decreased when MC degranulation was inhibited (Fig. 7B and C). Even though total VEGF mRNA decreased, no differences in the splicing process of VEGF gene following $M C$ stabilizer treatment were detected and VEGF164 remained as the main isoform (Fig. 7D). Using immunohistochemistry, an intense cytoplasmic VEGF staining was detected in epithelial, endothelial, and smooth muscle cells, while no expression was detected in MCs. VEGF was localized largely in the uterus pole of the uterine cervix rather than in the vaginal pole. It is interesting to emphasize that animals treated with $M C$ stabilizer showed a decreased expression of VEGF protein in the epithelial cells (Fig. 7E and F).

\section{Discussion}

In adulthood, angiogenesis occurs infrequently in physiological situations and the endothelium of most tissues is an extremely stable population of cells with a low mitotic rate. Exceptions are found in the female reproductive system where vascular growth and development should occur, for example, during pregnancy (Reynolds et al. 2002). Recently, we reported that the active angiogenic process that takes place in the rat uterine cervix during the second half of gestation is regulated, at least in part, by secretion of contents stored in MCs granules (Varayoud et al. 2004). Here, mechanistic information was added regarding this event. We suggest that MC degranulation may regulate the angiogenic process in the uterine cervix by modulating VEGF expression. The control of this process occurs at the primary transcript level because no changes in the processing of the alternative splice variants were found. 

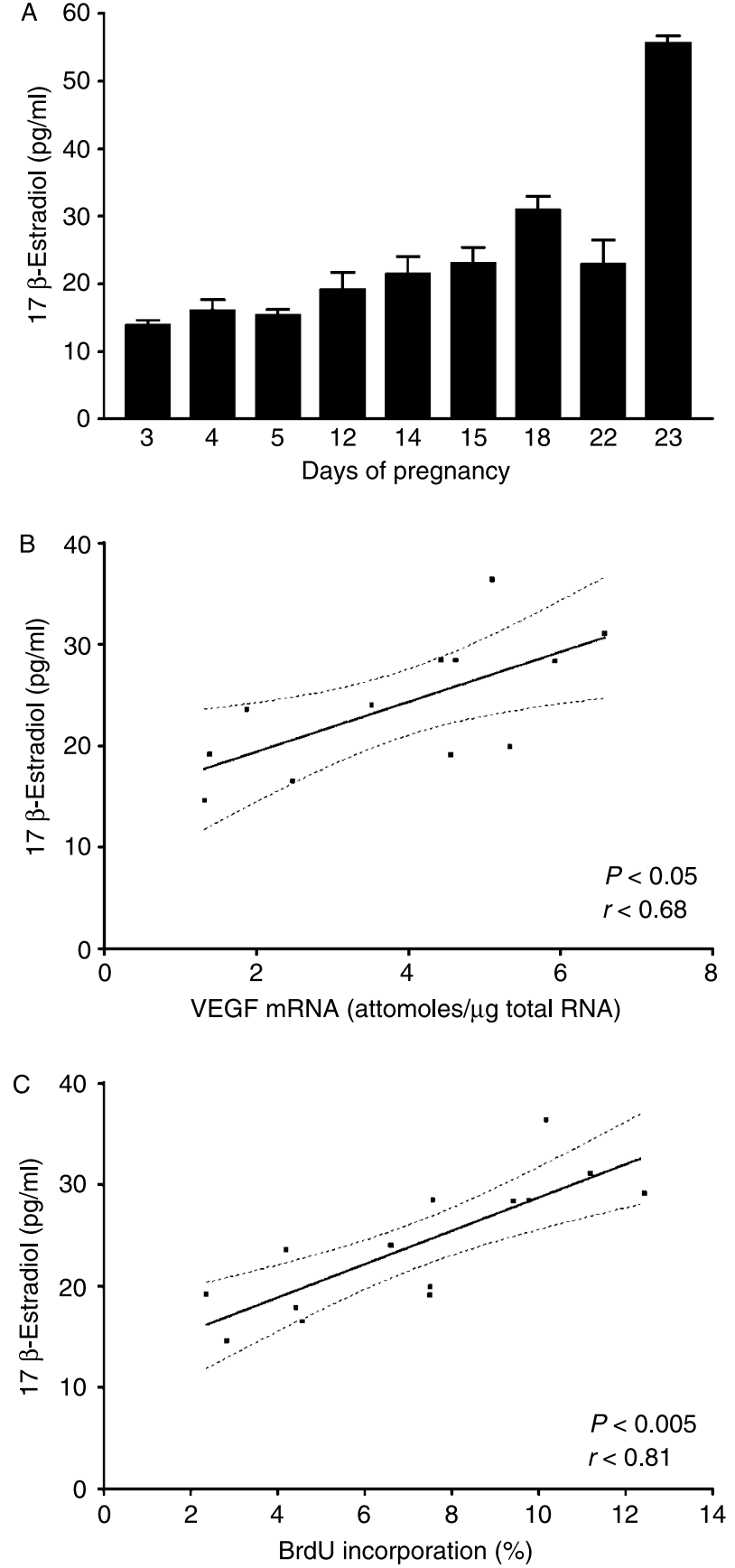

Figure $4 \mathrm{E}_{2}$ serum levels are associated with angiogenic parameters during pregnancy. (A) Serum $E_{2}$ concentrations from pregnant rats determined by RIA. $E_{2}$ levels were positively correlated with VEGF mRNA expression (B) and endothelial cell proliferation (C). Values are mean \pm s.E.M. of at least six animals per group.

It has been demonstrated that $\mathrm{E}_{2}$ regulates VEGF mRNA expression acting at the transcriptional level and involving $\mathrm{E}_{2}$ receptors (Kazi et al. 2005). Moreover, Karuri et al. (1998) showed physiological variations of the VEGF mRNA content in the rat uterus during the estrous cycle with a positive correlation with endogenous $E_{2}$ serum levels. In the present study, total
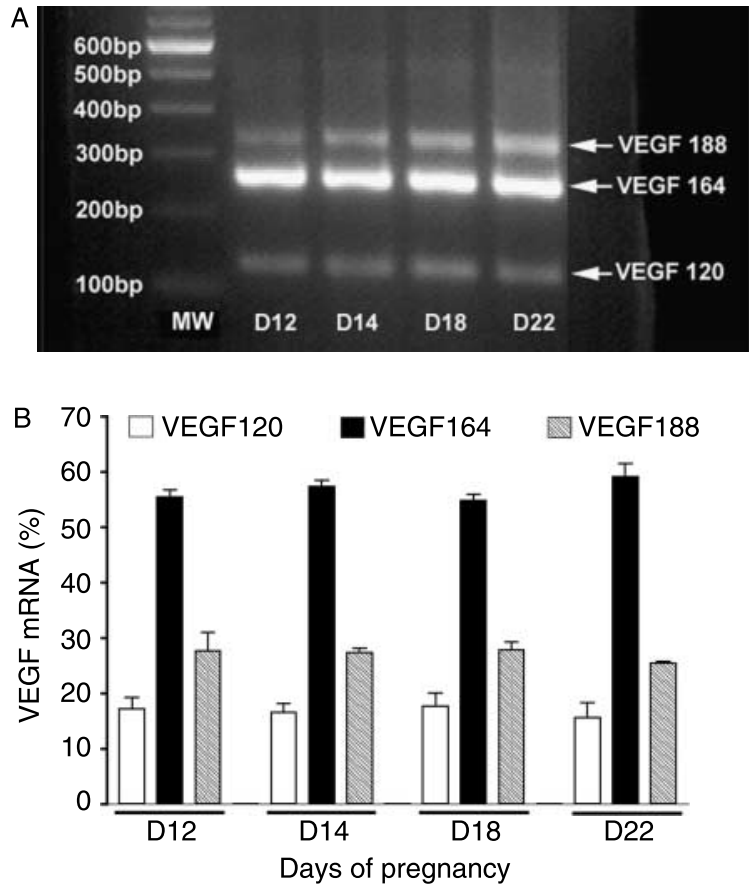

Figure 5 RT-PCR analyses of VEGF mRNA splice variants in the uterine cervix during pregnancy. (A) Representative $2 \%(\mathrm{w} / \mathrm{v})$ agarose gel stained with ethidium bromide showing RT-PCR products from uterine cervix obtained during gestation (D12, D14, D18, and D22). Bands correspond to three major variants of VEGF mRNA: 120 (126 bp), 164 (258 bp), and 188 (330 bp). MW, molecular weight marker. (B) Relative amounts of VEGF mRNA variants quantified by densitometry. Bars represent mean values \pm S.E.M. of six animals per group.

VEGF mRNA expression and $E_{2}$ serum levels were positively correlated suggesting that the estrogenic pathway could play a pivotal role in VEGF expression control in the uterine cervix during pregnancy.

Although VEGF has an important role in angiogenesis, very little is known about the regulation of VEGF mRNA processing in the rat uterine cervix during pregnancy. Recently, Mowa et al. (2004) found that the uterine cervix of pregnant rats clearly expresses two VEGF splice variants (VEGF164 and VEGF120) and they identified a faint band corresponding with the molecular weight of another variant (VEGF188). Previous work using rat uterine horns has described three splice variants of VEGF mRNA (188, 164, and 120; Cullinan-Bove \& Koos 1993, Long et al. 2001). In accordance with these results, we have identified the same three splice variants in the rat uterine cervix during pregnancy. The predominant splice variant was VEGF164 as it was reported by CullinanBove \& Koos (1993) and Mowa et al. (2004).

Regarding endothelial cell proliferation in the uterine cervix, BrdU incorporation was positively correlated with the VEGF mRNA pattern expression. Other authors (Phillips et al. 1990, Shweiki et al. 1993) observed a similar temporal relationship between VEGF mRNA expression and the formation of blood vessels in the reproductive system. Supporting these findings, the main 


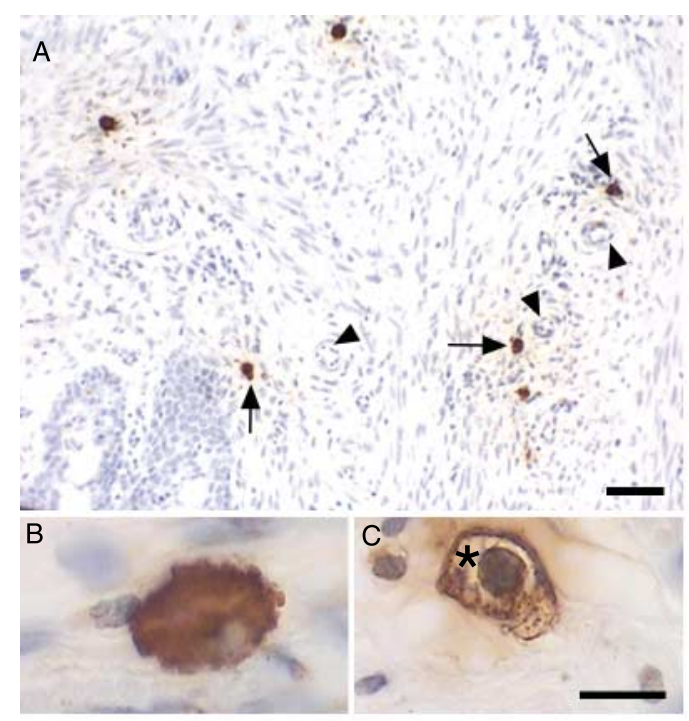

D

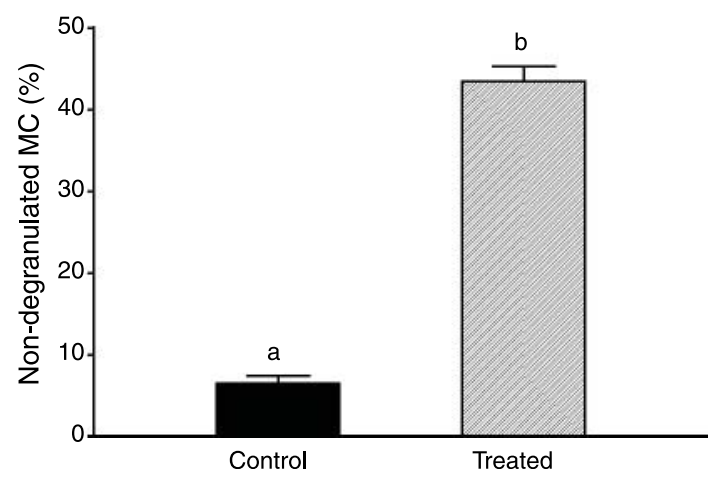

Figure 6 Immunohistochemical detection of MCs using anti-RMCP-I antibody. Low-magnification photomicrograph showing immunostained MCs (arrows) distribution in the uterine cervix on D12 of pregnancy; cells are usually localized near blood vessels (arrowhead) (A). MCs with densely packed granules showing no signs of degranulation (B) and MCs with features of degranulation showing empty cavities in the cytoplasm (asterisk) (C). Percentage of nondegranulated MCs was quantified as defined in Materials and Methods (D). Values are mean \pm s.E.M. of six animals per group. Scale bar represents $50 \mu \mathrm{m}$ in (A) and $10 \mu \mathrm{m}$ in (B) and (C).

activity of VEGF is to induce endothelial cell mitogenesis and to increase vascular permeability, which is believed to provide essential serum factors for new blood vessel growth (Norrby 1997, Robinson \& Stringer 2001, Ferrara et al. 2003). VEGF mediates its signals via high-affinity receptors with tyrosine kinases activity (VEGF-R) which results in the synthesis and release of proteases and specific integrins required for the initiation of endothelial cell proliferation and migration (Neufeld et al. 1999). Temporal agreement between the patterns of VEGF mRNA described here and the levels of VEGF receptors (VEGF-R1 and VEGF-R2) described by Mowa et al. (2004) are observed in the uterine cervix of pregnant rats. Therefore, taking into account that VEGF mRNA expression is regulated by $E_{2}$ and that VEGF is a potential mediator of endothelial proliferation, we suggest that
$\mathrm{E}_{2}-\mathrm{VEGF-VEGF-R} \mathrm{pathway} \mathrm{could} \mathrm{regulate} \mathrm{blood} \mathrm{vessel}$ formation in the rat uterine cervix during pregnancy.

The other aim of this study was to investigate whether chemical mediators contained in $\mathrm{MC}$ secretory granules could regulate VEGF expression in the rat uterine cervix. Using a previously described experimental model of pregnant rats treated with an MC stabilizer (Varayoud et al. 2004), here a significant fall was observed in the steady-state levels of VEGF mRNA expression in association with a decrease in endothelial cell proliferation. Moreover, when MC stabilizer-treated rats were compared with controls, the observations suggest that MCs regulated VEGF mRNA expression acting at the primary transcript level as there were no changes in the processing of the splice variants. In addition, no expression of VEGF protein was observed in MCs. VEGF was localized in epithelial, endothelial, and smooth muscle cells, showing in MC stabilizer-treated animals a decreased expression in luminal epithelium when compared with controls. Protein expression decrease correlated with the decrease in VEGF mRNA. Furthermore, VEGF mRNA expression was positively correlated with $E_{2}$ levels during D12 to D22 of pregnancy (control animals), while MC stabilizer-treated animals reduced the VEGF expression without exerting any variation in $E_{2}$ serum levels. Therefore, it is suggested that during gestation, VEGF expression and endothelial cell proliferation may be regulated by a mechanism controlled by both endogenous $\mathrm{E}_{2}$ levels and chemical mediators released from MCs. MCs release many mediators in response to non-immunogenic and immunogenic stimuli (Garfield et al. 2000, Rivera \& Gilfillan 2006). Estrogen promotes MC degranulation and histamine release and enhances the IgE-dependent $\mathrm{MC}$ activation. Since it has been shown that MCs express estrogen receptors and $E_{2}$ enhances $M C$ degranulation by genomic and non-genomic pathways (Cocchiara et al. 1992, Zaitsu et al. 2006), we could not discard the hypothesis that the MCs degranulation process and the consequent VEGF increase described here could be regulated by $E_{2}$. Further investigations are necessary to elucidate this event.

Recently, we showed that inhibition of MC degranulation affected the angiogenic process in the rat uterine cervix during pregnancy, suggesting that a hypoxic microenvironment may have been generated (Varayoud et al. 2004). In vitro studies showed that hypoxia induces macrophage's activation stimulating the release of angiogenic cytokines and factors, along with proteolytic enzymes that might play a role in the promotion of neovessel formation (Crowther et al. 2001). In accordance with these results, we observed that inhibition of $\mathrm{MC}$ degranulation increased macrophage numbers in rat uterine cervix and this effect was sustained beyond the end of treatment perhaps as a compensatory mechanism to warrant new vessel formation (Bosquiazzo et al. 2005). 

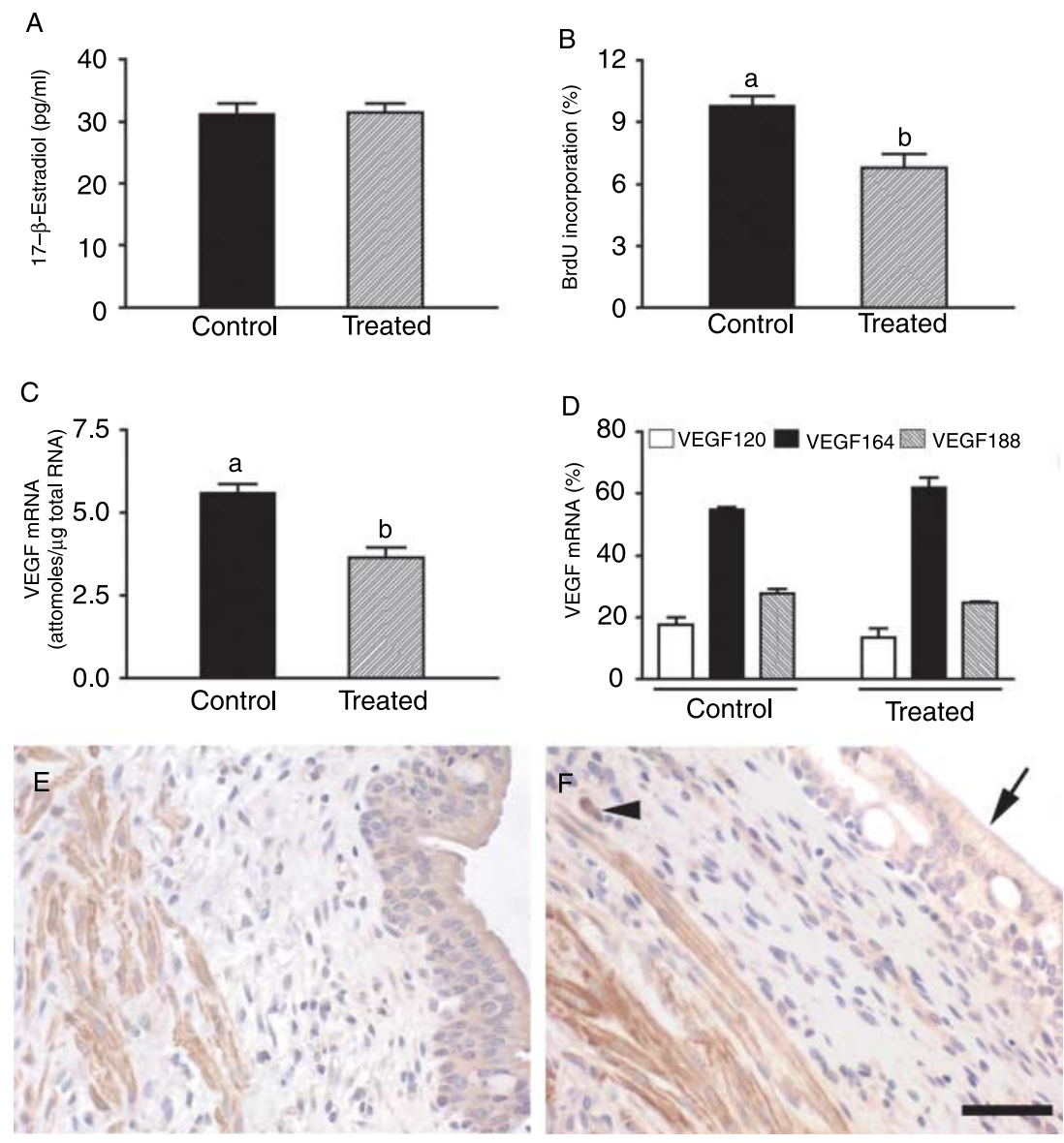

Figure 7 Effect of treatment with disodium cromoglycate on endothelial cell proliferation and VEGF expression in uterine cervix at D18 of gestation. (A) Serum levels of $17 \beta$-estradiol $\left(E_{2}\right)$. (B) Endothelial proliferation determined by $\mathrm{BrdU}$ incorporation. (C) Amounts of VEGF mRNA in control and treated animals, quantified by competitive RT-PCR. (D) Relative expression of the splice variants of VEGF mRNA determined by RT-PCR. (E and F) Photomicrographs of rat uterine cervix showing the expression pattern of VEGF in controls and disodium cromoglycate-treated animals respectively. Animals treated with MC stabilizer showed a decreased expression of VEGF protein in the epithelial cells (arrow). Arrowhead points out a VEGF-immunostained blood vessel. Bars represent means values \pm S.E.M. of at least six animals per group. Means with different letters represent statistically significant differences $(P<0.05)$. Scale bar represents $50 \mu \mathrm{m}$.
Mast cells can produce, store, and release many kinds of chemical mediators, including histamine, typtase, chymase, heparin proteoglycan, growth factors (bFGF, VEGF, and TGF- $\beta$ ), and cytokines (TNF- $\alpha$, IL- 6 , and IL-8). These cytokines have been involved in normal as well as in tumor-associated angiogenesis (Ribatti et al. 2001). In vitro studies showed that TNF $\alpha$ enhanced the production of IL-8, VEGF, and bFGF (Yoshida et al. 1997). Furthermore, previous reports indicate that VEGF mRNA expression can also be regulated by a number of cytokines and growth factors, such as TNF $\alpha$, TGF- $\beta$, bFGF, IL-1, and IL-6 (Neufeld et al. 1999, Taylor et al. 2001, Xie et al. 2004, Puxeddu et al. 2005). In this work, we used a physiological model to evaluate whether MC degranulation affects VEGF expression in the uterine cervix of pregnant rats. Based on present knowledge, this regulation could be exerted on one hand through two different signaling pathways: 1) direct pathway (autocrine): MCs could modulate their own VEGF synthesis and release or 2) indirect pathway (paracrine): MCs could produce a mediator (such as cytokines) that could regulate VEGF expression by other cells. On the other hand, Mowa et al. (2004) proposed that angiogenic and sensory neuronal factors may be important in regulating the dynamic microvasculature in the ripening cervix and they observed that VEGF is downregulated in the uterine cervix of pregnant rats after pelvic neurectomy. Therefore, a possible effect from vasoactive neuropeptides on $\mathrm{MC}$ regulation of angiogenic process in the uterine cervix could not be ruled out. Finally, the MC-stabilizing agent used in our work blocks the release of many substances from MC (Shin et al. 2004) and all of them could modulate angiogenesis. It may therefore be difficult to dissect the effect of a particular MC chemical mediator in our in vivo model.

Furthermore, relaxin is present in high levels in the peripheral circulation throughout the second half of pregnancy and plays a key role in promoting growth and softening the rat uterine cervix (Sherwood 1994). Relaxin is involved in blood vessel promotion in the uterine cervix during pregnancy (Burger \& Sherwood 1998) and stimulates the expression of VEGF in the genital tract (Unemori etal. 1999). Based on these data, neither a role of relaxin on angiogenesis during second half of pregnancy nor a possible effect of disodium cromoglycate treatment on the relaxin synthesis could be ruled out.

In conclusion, these results suggest that angiogenesis of the uterine cervix during gestation may be regulated by a mechanism which involves a control of endothelial proliferation by endogenous $E_{2}$ levels and an $M C$ degranulation-dependent pathway that implies the action of chemical mediators released from MCs. Both pathways 
mediate an upregulation of VEGF gene transcription, constituting an important regulatory step in cervical angiogenesis during pregnancy. Since cervical ripening entails a controlled inflammation-like process (Luque \& Montes 1989, Luque et al. 1996, Muñoz-de-Toro et al. 2003) and angiogenesis is intimately associated with inflammation, it is suggested that angiogenesis could be a significant component in the physiological mechanisms of cervical ripening. Consequently, and considering the well-established role of VEGF in angiogenesis (Norrby 1997, Hyder et al. 2000, Ferrara et al. 2003), this growth factor could play a significant role in remodeling cervical microvasculature for a normal parturition. These data provide the groundwork for future studies, which will examine the impact of the inhibition of $\mathrm{MC}$ degranulation and the decrease of VEGF expression on cervical ripening and parturition.

\section{Acknowledgements}

We are grateful to Mr Juan C Villarreal and Mr Juan Grant for their technical assistance and care of the animals. This study was supported by grants from the Argentine National Council for Science and Technology (CONICET) and the Argentine National Agency for the Promotion of Science and Technology (ANPCYT). VLB is a fellow and JGR, JV, and EHL are career investigators of the CONICET. The authors declare that there is no conflict of interest that would prejudice the impartiality of this scientific work.

\section{References}

Aoki M, Pawankar R, Niimi Y \& Kawana S 2003 Mast cells in basal cell carcinoma expresses VEGF, IL-8 and RANTES. International Archives of Allergy and Immunology 130 216-223.

Bosquiazzo VL, Durando M, Varayoud J, Ramos JG, Rodríguez HA, Muñoz-de-Toro M \& Luque EH 2005 Macrophage density in the pregnant rat uterine cervix is modulated by mast cell degranulation. Journal of Reproductive Immunology 65 147-158.

Burger LL \& Sherwood OD 1998 Relaxin increases the accumulation of new epithelial and stromal cells in the rat cervix during the second half of pregnancy. Endocrinology 139 3984-3995.

Byrne AM, Bouchier-Hayes DJ \& Harmey JH 2005 Angiogenic and cell survival functions of vascular endothelial growth factor (VEGF). Journal of Cellular and Molecular Medicine 9 777-794.

Camussi G, Montrucchio G, Lupia E, Soldi R, Comoglio PM \& Bussolino F 1997 Angiogenesis induced in vivo by hepatocyte growth factor is mediated by platelet-activating factor synthesis from macrophages. Journal of Immunology 158 1302-1309.

Chan YL, Lin A, McNally J, Peleg D, Meyuhas O \& Wool IG 1987 The primary structure of rat ribosomal protein L19. A determination from the sequence of nucleotides in a cDNA and from the sequence of amino acids in the protein. Biological Chemistry 262 1111-1115.

Cocchiara R, Albeggiani G, Di Trapani G, Azzolina A, Lampiasi N, Rizzo F, Diotallevi L, Gianaroli L \& Geraci D 1992 Oestradiol enhances in vitro the histamine release induced by embryonic histamine-releasing factor (EHRF) from uterine mast cells. Human Reproduction 7 1036-1041.

Crowther M, Brown NJ, Bishop ET \& Lewis CE 2001 Microenvironmental influence on macrophage regulation of angiogenesis in wounds and malignant tumors. Journal of Leukocyte Biology $\mathbf{7 0}$ 478-490.
Cullinan-Bove K \& Koos RD 1993 Vascular endothelial growth factor/vascular permeability factor expression in the rat uterus: rapid stimulation by estrogen correlates with estrogen-induced increases in uterine capillary permeability and growth. Endocrinology 133 829-837.

Ding YH, Li J, Zhou Y, Rafols JA, Clark JC \& Ding Y 2006 Cerebral angiogenesis and expression of angiogenic factors in aging rats after exercise. Current Neurovascular Research 3 15-23.

Eckhart L, Ban J, Ballaun C, Weninger W \& Tschachler E 1999 Reverse transcription-polymerase chain reaction products of alternatively spliced mRNAs form DNA heteroduplexes and heteroduplex complexes. Journal of Biological Chemistry 274 2613-2615.

Ferrara N \& Davis-Smyth T 1997 The biology of vascular endothelial growth factor. Endocrine Review 18 4-25.

Ferrara N, Gerber HP \& LeCouter J 2003 The biology of VEGF and its receptors. Nature Medicine 9 669-676.

Freeman ME 1988 The ovarian cycle of the rat. In The Physiology of Reproduction, pp 1893-1928. Eds E Knobil \& JD Neill. New York: Raven Press.

Garfield RE, Bytautiene E, Vedernikov YP, Marshall JS \& Romero R 2000 Modulation of rat uterine contractility by mast cells and their mediators. American Journal of Obstetrics and Gynecology 183 118-125.

Gibson S \& Miller HRP 1986 Mast cell subsets in the rat distinguished immunohistochemically by their content of serine proteinases. Immunology 58 101-104.

Goede V, Schmidt T, Kimmina S, Kozian D \& Augustin HG 1998 Analysis of blood vessel maturation processes during cyclic ovarian angiogenesis. Laboratory Investigation 78 1385-1394.

Goth MI, Hubina E, Raptis S, Nagy GM \& Toth BE 2003 Physiological and pathological angiogenesis in the endocrine system. Microscopy Research and Technique 60 98-106.

Griffioen AW \& Molema G 2000 Angiogenesis: potentials for pharmacologic intervention in the treatment of cancer, cardiovascular diseases, and chronic inflammation. Pharmacological Reviews 52 237-268.

Gunin AG \& Sharov AA 1998 Role of mast cells in oestradiol effects on the uterus of ovariectomized rats. Journal of Reproduction and Fertility 112 61-68.

Halder JB, Zhao X, Soker S, Paria BC, Klagsbrun M, Das SK \& Dey SK 2000 Differential expression of VEGF isoforms and VEGF(164)specific receptor neuropilin-1 in the mouse uterus suggests a role for VEGF(164) in vascular permeability and angiogenesis during implantation. Genesis 26 213-224.

Heryanto B \& Rogers PA 2002 Regulation of endometrial endothelial cell proliferation by oestrogen and progesterone in the ovariectomized mouse. Reproduction 123 107-113.

Hyder SM, Stancel GM, Chiappetta C, Murthy L, Boettger-Tong HL \& Makela S 1996 Uterine expression of vascular endothelial growth factor is increased by estradiol and tamoxifen. Cancer Research $\mathbf{5 6}$ 3954-3960.

Hyder SM, Nawaz Z, Chiappetta C \& Stancel GM 2000 Identification of functional estrogen response elements in the gene coding for the potent angiogenic factor vascular endothelial growth factor. Cancer Research 60 3183-3190.

Karuri AR, Kumar AM \& Mukhopadhyay D 1998 Differential expression and selective localization of vascular permeability factor/vascular endothelial growth factor in the rat uterus during the estrous cycle. Journal of Endocrinology 159 489-499.

Kashida S, Sugino N, Takiguchi S, Karube A, Takayama H, Yamagata Y, Nakamura Y \& Kato H 2001 Regulation and role of vascular endothelial growth factor in the corpus luteum during midpregnancy in rats. Biology of Reproduction 64 317-323.

Kass L, Varayoud J, Ortega H, Muñoz-de-Toro M \& Luque EH 2000 Detection of bromodeoxyuridine in formalin-fixed tissue. DNA denaturation following microwave or enzymatic digestion pretreatment is required. European Journal of Histochemistry 44 185-191.

Kass L, Durando M, Ramos JG, Varayoud J, Powell CE, Luque EH \& Muñoz-de-Toro M 2004 Association of increased estrogen receptor 
$\beta 2$ expression with parity-induced alterations in the rat mammary gland. Journal of Steroid Biochemistry and Molecular Biology 91 29-39.

Kazi AA, Jones JM \& Koos RD 2005 Chromatin immunoprecipitation analysis of gene expression in the rat uterus in vivo: estrogeninduced recruitment of both estrogen receptor $\alpha$ and hypoxiainducible factor 1 to the vascular endothelial growth factor promoter. Molecular Endocrinology 19 2006-2019.

Long X, Burke KA, Bigsby RM \& Nephew KP 2001 Effects of the xenoestrogen bisphenol A on expression of vascular endothelial growth factor (VEGF) in the rat. Experimental Biology and Medicine 226 477-483.

Luque EH \& Montes GS 1989 Progesterone promotes a massive infiltration of the rat uterine cervix by the eosinophilic polymorphonuclear leukocytes. Anatomical Record 223 257-265.

Luque EH, Ramos JG, Rodriguez HA \& Muñoz-de-Toro MM 1996 Dissociation in the control of cervical eosinophilic infiltration and collagenolysis at the end of pregnancy or after pseudopregnancy in ovariectomized steroid-treated rats. Biology of Reproduction $\mathbf{5 5}$ 1206-1212.

Luque EH, Muñoz de Toro MM, Ramos JG, Rodriguez HA \& Sherwood OD 1998 Role of relaxin and estrogen in the control of eosinophilic invasion and collagen remodelling in rat cervical tissue at term. Biology of Reproduction 59 795-800.

Ma W, Tan J, Matsumoto H, Robert B, Abrahamson DR, Das SK \& Dey SK 2001 Adult tissue angiogenesis: evidence for negative regulation by estrogen in the uterus. Molecular Endocrinology 15 1983-1992.

Montes GS \& Luque EH 1988 Effects of ovarian steroids on vaginal smears in the rat. Acta Anatomica 133 192-199.

Mowa CN, Jesmin S, Sakuma I, Usip S, Togashi H, Yoshioka M, Hattori Y \& Papka R 2004 Characterization of vascular endothelial growth factor (VEGF) in the uterine cervix over pregnancy: effects of denervation and implications for cervical ripening. Journal of Histochemistry and Cytochemistry 52 1665-1674.

Muñoz-de-Toro M, Varayoud J, Ramos JG, Rodríguez H \& Luque EH 2003 Collagen remodeling during cervical ripening is a key event for successful vaginal delivery. Brazilian Journal of Morphological Sciences 20 75-84.

Neufeld G, Cohen T, Gengrinovitch S \& Poltorak Z 1999 Vascular endothelial growth factor (VEGF) and its receptors. FASEB Journal 13 9-22.

Norrby K 1997 Angiogenesis: new aspects relating to its initiation and control. Acta Pathologica, Microbiologica et Immunologica Scandinava 105 417-437.

Phillips HS, Hains J, Leung DW \& Ferrara N 1990 Vascular endothelial growth factor is expressed in rat corpus luteum. Endocrinology $\mathbf{1 2 7}$ 965-967.

Puxeddu I, Ribatti D, Crivellato E \& Levi-Schaffer F 2005 Mast cells and eosinophils: a novellink between inflammation and angiogenesis in allergic diseases. Journal of Allergy and Clinical Immunology 116 531-536.

Rabbani ML \& Rogers PA 2001 Role of vascular endothelial growth factor in endometrial vascular events before implantation in rats. Reproduction 122 85-90.

Reynolds LP, Grazul-Bilska AT \& Redmer DA 2002 Angiogenesis in the female reproductive organs: pathological implications. International Journal of Experimental Pathology 83 151-163.
Ribatti D, Crivellato E, Candussio L, Nico B, Vacca A, Roncali L \& Dammacco F 2001 Mast cells and their secretory granules are angiogenic in the chick embryo chorioallantoic membrane. Clinical and Experimental Allergy 31 602-608.

Rivera J \& Gilfillan AM 2006 Molecular regulation of mast cell activation. Journal of Allergy and Clinical Immunology $\mathbf{1 1 7}$ 1214-1225.

Robinson CJ \& Stringer SE 2001 The splice variants of vascular endothelial growth factor (VEGF) and their receptors. Journal of Cell Science 114 853-865.

Roy H, Bhardwaj S \& Ylä-Herttuala S 2006 Biology of vascular endothelial growth factors. FEBS Letters $\mathbf{5 8 0} 2879-2887$.

Sherwood OD 1994 Relaxin. In The Physiology of Reproduction, pp 861-1009. Eds E Knobil \& JD Neill. New York: Raven Press.

Shin HY, Kim JS, An NH, Park RK \& Kim HM 2004 Effect of disodium cromoglycate on mast cell-mediated immediate type allergic reactions. Life Sciences $\mathbf{7 4}$ 2877-2887.

Shweiki D, Itin A, Neufeld G, Gitay-Goren H \& Keshet E 1993 Patterns of expression of vascular endothelial growth factor (VEGF) and VEGF receptors in mice suggest a role in hormonally regulated angiogenesis. Journal of Clinical Investigation 91 2235-2243.

Siegel S 1956 Nonparametric Statistics for the Behavioral Sciences, New York: McGraw-Hill.

Sugihara T, Wadhwa R, Kaul SC \& Mitsui Y 1998 A novel alternatively spliced form of murine vascular endothelial growth factor, VEGF 115. Journal of Biological Chemistry 273 3033-3038.

Taylor RN, Lebovic DI, Hornung D \& Mueller MD 2001 Endocrine and paracrine regulation of endometrial angiogenesis. Annals of the New York Academy of Sciences 943 109-121.

Unemori EN, Erikson ME, Rocco SE, Sutherland KM, Parsell DA, Mak J \& Grove BH 1999 Relaxin stimulates expression of vascular endothelial growth factor in normal human endometrial cells in vitro and is associated with menometrorrhagia in women. Human Reproduction 14 800-806.

Varayoud J, Ramos JG, Bosquiazzo VL, Muñoz-de-Toro M \& Luque EH 2004 Mast cells degranulation affects angiogenesis in the rat uterine cervix during pregnancy. Reproduction 127 379-387.

Walter LM, Rogers PA \& Girling JE 2005 The role of progesterone in endometrial angiogenesis in pregnant and ovariectomized mice. Reproduction 129 765-777.

Xie K, Wei D, Shi Q \& Huang S 2004 Constitutive and inducible expression and regulation of vascular endothelial growth factor. Cytokine and Growth Factor Reviews 15 297-324.

Yoshida S, Ono M, Shono T, Izumi H, Ishibashi T, Suzuki H \& Kuwano M 1997 Involvement of interleukin-8, vascular endothelial growth factor, and basic fibroblast growth factor in tumor necrosis factor alpha-dependent angiogenesis. Molecular and Cellular Biology 17 4015-4023.

Zaitsu M, Narita S, Lambert KC, Grady JJ, Estes DM, Curran EM, Brooks EG, Watson CS, Goldblum RM \& Midoro-Horiuti T 2006 Estradiol activates mast cells via a non-genomic estrogen receptor-alpha and calcium influx. Molecular Immunology 44 1987-1995.

Received 25 August 2006

First decision 16 October 2006

Revised manuscript received 19 January 2007

Accepted 20 February 2007 